\title{
Research on the exports trade of Shandong agricultural products ${ }^{*}$
}

\author{
LI Bing ${ }^{1,2}$ \\ (1. School of International Trade, Shandong Economic University, Jinan 250014, China; \\ 2. School of International Trade and Economics, University of International Business and Economics, Beijing 100029, China)
}

\begin{abstract}
This paper analyses the internal problems and external constraints against the further development of exports trade of Shandong agricultural products. The countermeasures in solving those problems and constraints are recommended to ensure a sustainable development of Shandong regional agricultural products exports.
\end{abstract}

Key words: export trade; Shandong agricultural products; sustainable development

\section{Introduction}

Shandong is a major provincial exporter of agricultural products, whose agricultural products exports are about 1/4 of the China's total exports. From the "10th Five-Year Plan” period to 2007, Shandong agricultural exports grew from UDS2.79 billion to USD9.35 billion with average annual growth rate of $20 \%$ or more. Shandong ranks the biggest exporter for eight consecutive years in China and the proportion of Shandong's agricultural exports in the total provincial agricultural output amounted to more than $15 \%$.

\section{Main internal problems and external constraints}

Though Shandong agricultural products exports achieved a big success all over the China, there are still some existing internal problems and external constraints that hinder its further and sustainable developments.

\subsection{Existing main internal problems}

The first problem is that export product structure is still not optimized yet. The export consists of too many primary products which have small margin of added value. In recent years, restructuring of agricultural products always heads for the increase of quantity, not much for increase of quality. Many such low-quality products are not suitable for market development and having little profit margin.

The second problem is that Shandong agricultural export market is still relatively too concentrated to specific countries. Japan is the largest agricultural exporting country for Shandong Province, accounting for $40 \%$ of total Shandong's agricultural export. In 2004, Shandong exported USD1.28 billion to Japan, accounting for 37\% of total provincial agricultural export. In 2006, Shandong exported USD2.87 billion to Japan, accounting for 35.5\% of the total exports. In 2007, the amounts went to USD2.85 billion, 30.8\% of the total. ${ }^{1}$ Although the share dropped, Japan market is still the largest export market for Shandong Province. EU, the United States and South

\footnotetext{
* This research paper was supported by the Shandong Natural Science Fund Project (No. 2007ZRB01493), Shandong Social Science Fund (No. 07DJGZ05) and Shandong Soft Science Project (No. 2008RKB269).

LI Bing, Ph.D., associate professor of School of International Trade, Shandong Economic University, postdoctor of School of International Trade and Economics, University of International Business and Economics; research fields: international trade, foreign direct investment.

${ }^{1}$ Data source: China Statistical Bureau Data. http://www.stats.gov.cn.
} 
Korea are the other major agricultural export countries and regions for Shandong. The changes on agricultural imports policy in these countries shall have a great impact upon the export of Shandong agricultural products.

The third problem is that the enterprise scale of Shandong province is still small and competition is in disorder. The general small-scale agricultural products enterprises and the rapid expansion of the same companies lead to intensified competition and cause the serious damages to interests of agricultural industry. According to WTO commitments, China gradually granted the licensing right of import and export to all businesses. The number of companies and enterprises joined the team of agricultural exports reached 20,000 in 2007, but the small-scale enterprises' average export value was only about USD1 million while the enterprises with a export value of over USD10 million are less than $3 \%$ of the total enterprises.

The fourth problem is that agricultural products branding and marketing network construction are seriously lagged behind. Shandong domestic enterprises export largely depended on foreign sales agents and foreign marketing. Although the scale of agricultural exports continues to expand, OEM production is currently the main way of export due to absence of brand building. This caused the lack of well-known brand in the international agricultural products market and not only resulted in Shandong Province agricultural exports meager profits, but also caused Shandong Province exports of agricultural products strong dependence on foreign investors.

\subsection{Main external constraints}

The appreciation of the RMB is a major external constraint against Shandong agricultural products exports. Since RMB exchange rate formation mechanism reform in 2005, the flexibility of the RMB exchange rate is growing rapidly. On April 10, 2008, the exchange rate of RMB against the U.S. dollar broke 7, appreciation about $18.2 \%$ compared to that before the reform. Currently, RMB continues to remain strong. Because agricultural production and processing enterprises have low levels of overall profit margin, the appreciation of the RMB further reduced the profit margin of the export of agricultural products, which have a great impact on the international competitiveness of Shandong agricultural products.

The increased production cost is the second main constraint. On one hand, because of the increased prices of oil, fertilizer, farm diesel and plastic materials, the costs of agricultural cultivation, breeding, fishing and transportation go up and these pull the agricultural raw materials prices up accordingly. For example, mackerel fish price rose from RMB 2,000/ton by the end of 2004 to RMB 10,000/ton in 2007. On the other hand, as a labor-intensive industry, because of tight labor and employment supply, wages of migrant workers rose, too. This greatly affected the products processing enterprises. The average wage in Yantai Long Da Group has been rising from RMB500 in 2002 to RMB 1,000 in 2007, which shall add more than RMB100 million on annual wage spending. (YANG Lian-na, 2007)

The increased international agricultural trade protection is the third major constraint. In contrast to China's gradual opening up its domestic market according to WTO requirements, the international agricultural trade protection has become increasingly popular. Countries all over the world use the issues around the ecological environment, animal welfare, intellectual property, quality standards, and other forms of social responsibility to protect its agriculture. In 2006, the implementation of "New Food Law” of EU (XIE Zheng-qin, 2006) and "Positive List System” of Japan (NI Yue-ju, 2006) had had the greatest impacts on China’s export. In June, 2006, China's total agricultural products exports to Japan were USD596 million, USD131 million less than that in the same period 2005, down 18\%. In the same month for Shandong Province, the exports to Japan was USD215 million, down 7.8\%. As a No.1 leading agricultural products exporter, Shandong Province is faced with an unprecedented pressure on exports of agricultural products. 


\section{Countermeasures in keeping the sustainable developments of Shandong agricultural products exports}

Shandong agricultural products exports are faced with many problems and constraints, but there are still countermeasures that can be adopted to keep the sustainable developments of Shandong agricultural products exports.

\subsection{The quality and safety of Shandong agricultural products should be further improved}

The quality and safety of agricultural products are the keys to keep the export sustainable development for Shandong Province. Improving the quality and safety of agricultural products exports not only can deal with the current positive list system of Japan, but also can strengthen the core competitiveness of Shandong agricultural products in the future. Measures should be taken to support enterprises obtaining ISO22000 certification and HACCP certification (XU Bo-yuan, 2007). System of quality tracing back should be established to promote the setting of good agricultural products practices. Central test laboratory should be established for the regional testing convenience and good regulation.

\subsection{New sectors development should be accelerated}

Following the changes of demand in high-end markets, Shandong should not only continue to develop traditional sectors in aquatic products, vegetables, animal products, fruits and other traditional agricultural exports on the basis of comparative advantages, but also accelerate the development of new sectors in flowers, seeds and edible fungi. Thus a new export structure of mutual promotion and coordination of traditional and new sectors could be set up.

\subsection{Cultivation a number of leading enterprises should be the focus}

Flexible mechanism and efficient functioning are the essences of agricultural industry management which focuses on the leading role played by the leading enterprises. The measures should be taken to further support and nurture a number of leading enterprises with wide association of industries, high technology, strong international competitiveness, large export scale, good efficiency and mass job creating functions.

\subsection{Brand-building and intellectual property right protection should be promoted}

Independent brand is a powerful weapon for the expansion of exports and it is conducive to the maintenance of old customers and new market development. It is necessary to actively promote the changes from OEM production to independent brands production. Focuses should be put on brand-building in large enterprises which should be supported to develop their own products intellectual property rights and conduct trade mark registration and product quality certification abroad.

\subsection{Marketing maintenance and diversification should be paid same attention}

Shandong should continue to maintain and explore key markets such as Japan, the European Union, the United States and other agricultural products export areas, which are the high-end market with high prices and good profit return. Shandong should also develop emerging markets in South Asia, the Middle East, Latin America, Russia and other regions to diversify the market structure to ensure the sustainable development and avoid market risks.

\subsection{New key products trade associations should be established}

Following the successful experiences of forming garlic and rabbit meat export associations, new trade associations on aquatic products, poultry meat, vegetables, fruits, peanut and other key export products should be established to guide the development of agricultural industry and prevent the disorderly competition by the domestic enterprises in the international market.

(to be continued on Page 66) 